\title{
Claude Bernard: bicentenary of birth and his main contributions to neurology
}

\author{
Claude Bernard: bicentenário do nascimento e suas principais contribuições à neurologia
} Marleide da Mota Gomes ${ }^{1}$, Eliasz Engelhardt ${ }^{2}$

\begin{abstract}
Claude Bernard (1813-1878) followed two main research paths: the chemical and physiological study of digestion and liver function, along with experimental section of nerves and studies on sympathetic nerves. Curare studies were, for example, of longstanding interest. His profound mental creativity and hand skillfulness, besides methodology quality, directed his experiments and findings, mainly at the Collège de France. His broader and epistemological concerns were carried out at the Sorbonne and later at the Muséum national d'Histoire naturelle. His insight gave clues to define the "milieu intérieur", later known as "homeostasis", and grasp the brain complexity. Bernard followed and surpassed his master François Magendie who also fought against dogmas and laid the foundations of experimental medicine, and its main heinous tool - vivisection. Bernard created the methodological bases of experimental medicine, and collected honors as a renowned researcher.
\end{abstract}

Keywords: Claude Bernard, sympathetic nerves, homeosthasis, epistemology, history of neurosciences.

\section{RESUMO}

Em suas pesquisas, Claude Bernard (1813-1878) seguiu dois caminhos principais: o estudo fisiológico e químico da digestão e da função hepática; a seção experimental de nervos e os estudos sobre nervos simpáticos. Estudos sobre curare, por exemplo, foram de interesse duradouro. Suas profundas criatividade mental e habilidade manual, além da qualidade metodológica, conduziram às suas experiências e descobertas, principalmente no Collège de France. Seus interesses sobre temas epistemológicos mais amplos foram conduzidos na Sorbonne e, posteriormente, no Muséum national d'Histoire naturelle. Seu discernimento deu subsídios para definir o "milieu intérieur ", mais tarde conhecido como "homeostase", e para ajudar a compreender a complexidade do cérebro. Bernard seguiu e superou seu mestre François Magendie. Este também lutou contra dogmas e lançou os fundamentos da medicina experimental, utilizando sua principal ferramenta hedionda - a vivissecção. Bernard ampliou estes estudos e criou as bases metodológicas da medicina experimental, tendo colecionado honrarias como renomado pesquisador.

Palavras-chave: Claude Bernard, nervos simpáticos, homeostasia, epistemologia, história das neurociências.

Claude Bernard (1813-1878) was the founder of modern physiology, pharmacology and experimental medicine, and his findings and insights on nervous functions are here succintly presented.

\section{BERNARD'S EARLY LIFE, SOCIAL REMARKS, AND ACADEMIC CAREER}

Bernard was born in the village of Saint-Julien, near Villefranche-sur-Saône and Lyon ${ }^{1}$. He was the son of a modest proprietor of vineyards and wine merchant. He received his early education in the Jesuit school of Villefranche (18211831), and then proceeded to the college, where he soon left to become an apprentice in a pharmacy, and periodic visitor to a nearby veterinary school in Lyon ${ }^{1}$. From there, he went to Paris to consult a famous theater critic who did not valorize his inclination to write theater plays, but recommend him instead to exploit his pharmacy experience and enter medicine ${ }^{2}$. He enrolled at the Faculty of Medicine of Paris (1834), and was approved for externship (1836), and the internship (1839), under the sponsorship of François Magendie (1783-1855), in the Hotel Dieu ${ }^{1,2}$. As usual, even in the medicine course, he did not excel in his formal

\footnotetext{
${ }^{1}$ Programa de Epilepsia, Faculdade de Medicina, Instituto de Neurologia Deolindo Couto, Universidade Federal do Rio de Janeiro, Rio de Janeiro RJ, Brazil; ${ }^{2}$ Setor de Neurologia Cognitiva e do Comportamento, Instituto de Neurologia Deolindo Couto and Instituto de Psiquiatria, Universidade Federal do Rio de Janeiro, Rio de Janeiro RJ, Brazil

Correspondence: Marleide da Mota Gomes; Instituto de Neurologia Deolindo Couto, Universidade Federal do Rio de Janeiro; Avenida Venceslau Braz 95; 22290-140 Rio de Janeiro RJ - Brasil; E-mail:mmotagomes@acd.ufrj.br

Conflict of interest: There is no conflict of interest to declare.
}

Received 11 September 2013; Received in final form 24 September 2013; Accepted 01 October 2013. 
studies $^{3}$. In 1841, Magendie discovered Bernard's dissecting skills and took him on as his laboratory assistant ${ }^{2,3}$. In 1843, Bernard become physician, and in 1845 he married a Parisian wealthy doctor's daughter, but the unhappy couple was officially separated in $1870^{1}$. However, much of his work was carried out between 1843-1858 in a little moist basement, with limited funding ${ }^{3}$. In 1847, he was appointed Magendie's substitute at the Collège de France, and in 1855 he took the Chair of Physiology, held previously by Magendie and Laennec, and later occupied by Charles Edouard Brown-Séquard (1878)². Bernard took over also the chair of experimental physiology created for him at the Sorbonne University (1854), but in 1868 this chair was transferred from the Sorbonne to the Muséum national d'Histoire naturelle. He was also elected to the Academy of Sciences, the Academy of Medicine, and Imperial Senate - a nomination made by the emperor Napoleon III. In conclusion, he was extensively admired, including by the Brazilian emperor, Dom Pedro $\mathrm{II}^{1,2}$. However, some authors argue that he trivialized the significance of clinical and epidemiological studies, but Morabia ${ }^{4}$ gave Bernard's mainstream thought: "He was realistic about statistics and comparative therapeutic trials and virulent against irrational medicine." Much of his work was based on animal vivisection (Figure 1), and many people opposed to this shocking disrespect regarding the well-being of the experimental animal, including his wife and daughters ${ }^{1,3}$. However, considering his precious contributions, Bernard had the first French funeral settled to a scientist. This happened after a declining health (1859-1978), with chronic painful enteritis, rheumatism, unrelenting migraines, and abrupt health deterioration after kidney infection ${ }^{1,2}$.

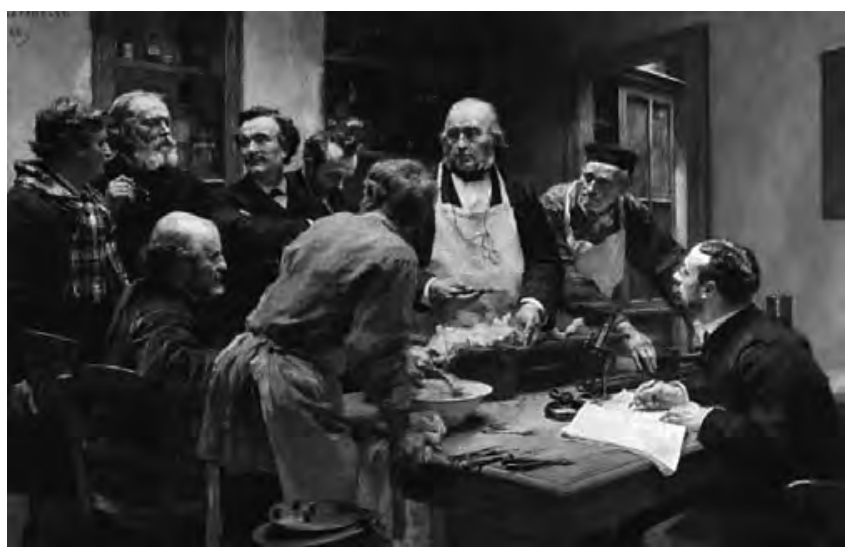

Figure 1. Bernard's laboratory and associates (The Lesson of Claude Bernard or Session at the Vivisection Laboratory -1889 by Leon Augustin Lhermitte - 1844-1925, Académie de Médecine, Paris, France)3. http://fr.wikipedia.org/wiki/Claude_ Bernard

\section{BERNARD'S MAIN SCIENTIFIC ACHIEVEMENTS IN NEUROPHYSIOLOGY}

Bernard shed light on the role of the pancreas in digestion, and the liver in creating glucose, for instance. Aditionally, he undertook research on neurophysiology by assisting Magendie on spinal nerves studies. His first communication (1843) was on Recherches anatomiques et physiologiques sur la corde du tympan, pour servir a l'histoire de Phemiplegie faciale. This was the beginning of a long series of investigations on the relations of nerves to secretion, temperature and vasomotricity ${ }^{2,5}$ (Figure 2). One important landmark in his $^{6,7}$ career was the discovery of the sympathetic nervous system control of heat regulation and blood flow, through vasodilator and vasoconstrictor functions, as initially identified by Brown-Séquard, and acknowledged by Bernard many years later (Figure 3). In 1851, he reported an increase in temperature in the corresponding side of the face (including the ears) as an effect of sectioning the cervical branch of the great sympathetic in rabbits, he attributed to "calorification" (an increase of temperature) due to a more active circulation ${ }^{6}$. In 1852, Bernard reported that the galvanization of the peripheral extremity of the cut sympathetic nerve produced exactly opposite effects, reverting the temperature rise, accompanied by paleness of the ear. He also describe in detail the effects of such section-galvanization experiments on the pupil, eyelid, and ocular globe, the basis of a syndrome named after him ${ }^{6}$. Moreover (1858), he showed that chorda tympani excitation dilates the vessels of the submandibular gland, while secretory activity enters ${ }^{2}$. In this way, he discovered that the sympathetic nerve was the constrictor of the blood vessels and the chorda tympani a dilator. Consequently, he established the concept of the physiological equilibrium of the two antagonistic innervations. Bernard (1858), in his lessons on the nervous system, traced the modern distinctions between neuronal and muscle paralysis causes through the use of curare, a topic of extreme interest to him since 1844. He was the first to reveal that curare blocked the nerve stimulation of muscles, but he suggested that the blocked muscle contractions was due to a direct action on the nerve. He did not distinguished a specic junction between nerve and muscle. However, his pupil Alfred Vulpian (1826-1887) suggested that curare acted on the motor endplate ${ }^{8}$. These studies led Bernard to study asphyxia and anesthetics, besides, the receptor concept started with the curare studies (1856), providing the basis of the synapse and neuron theory ${ }^{7}$. Bernard demonstrated also that simple reflex movements were due to the influence of sensory roots exerted on the motor roots. He discovered moreover the production of diabetes by puncture of the floor of the fourth ventricle (1849), interpreted by many as being the result of excessive stimulation of the liver by secretory nerves. Furthermore, he postulated that living organisms 


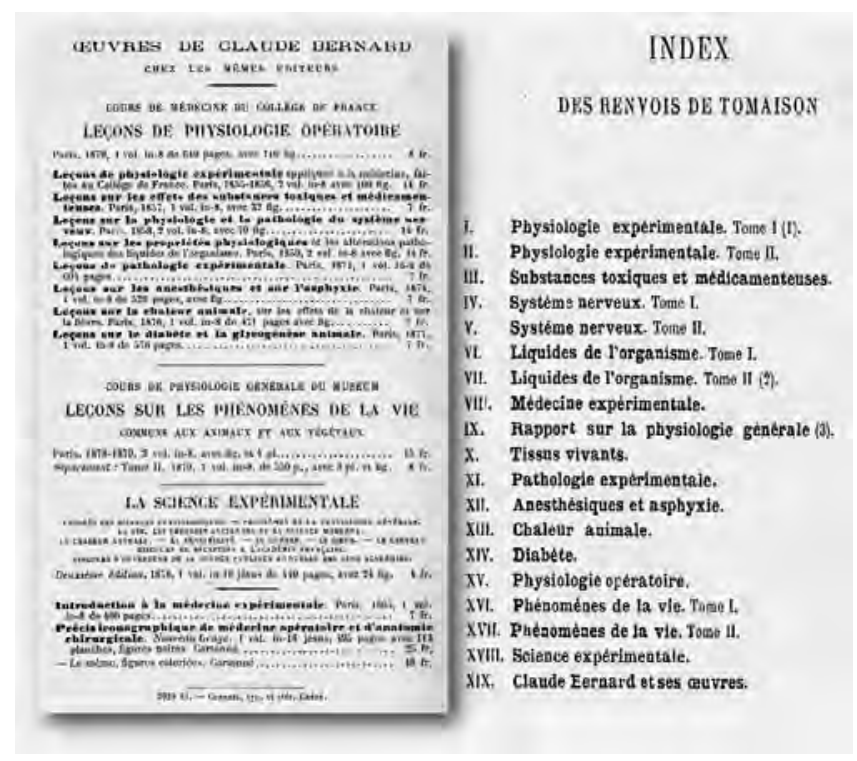

Figure 2. "L 'Oeuvre de Claude Bernard"5 (1881) is the Bernard's exposition of his views and some of the original facts that may be examined in his published lectures and in posthumous praises. Two groups of studies may envisaged, the works at the College of France, analytical and dedicated to his own research, and those at the Sorbonne-Museum, of a more general character. Some issues have more direct link to neurology. In 1857, Bernard published "Lessons on the Effects of Toxic Substances and Drug" where many studies of the toxicological properties of neuroactive compounds, such as curare, opium, atropine, strychnine and nicotine where presented7. In 1858, Bernard published "Lessons on the physiology and pathology of the nervous system" (see more details on Figure 3). "The Experimental Science" (1878) is a collection of works that include subjects such as curare and brain. About curare, Bernard mentions." In 1844, I received from Mr. Pelouze poisoned arrows and curare. In 1848, a young Brazilian who took my courses, Dr. Edwards, gave me curare. "In June 1844, I had my first experience with curare." "In our physiological analysis, we got to locate the action of the poison on the nervous motor element". The last text (about the brain) is one originally published on Revue des Deux Mondes (1872) "The functions of the brain." It is based on animal experiments with its common methodology and human cerebral lesions, Bernard realized that "Physiology shows that despite the differences observed and the greater complexity of the phenomena, the brain is the organ of intelligence as well as the heart is the organ of circulation, organs and their functions, it is a general principle that no organ of the body can escape."

possessed sensors that regulate their internal environment, $L e$ Milieu Intérieur (1857), later known as "homeostasis". His concept of the central physiological control of the "milieu intérieur" was held in opposition to the old theory of "vitalism". He considered that the regulation of vital functions was the leading function of the brain, and he lead to a

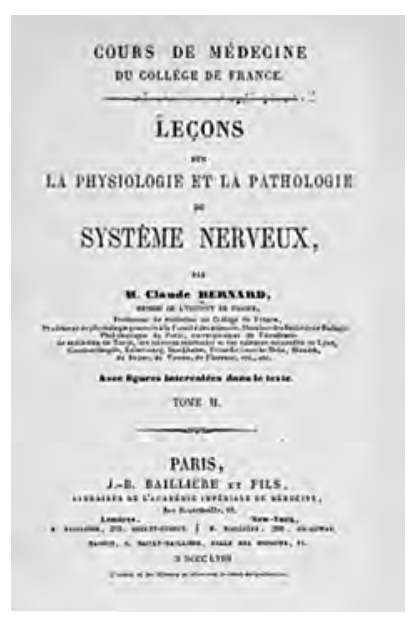

Figure 3. Leçons sur la Physiologie et la Pathologie du Systhème Nerveux ${ }^{6}$ : in the $1^{\text {st }}$ volume, the nerve proprieties and centers are examined. Great attention is given to controversies about the recurrent sensitivity. Artificial diabetes produced by lesion of the floor of the fourth ventricle, and many other experiments on the spinal cord are described. In the $2^{\text {nd }}$ volume, nerves are studied, including of the face, and the vagus. Many details are granted for the spinal accessory nerve, and meticulous attention is provided for the sympathetic, mostly on its influence on circulation related to heat action (calorification). "I presented these results in lessons delivered in 1852, and they were printed in October and November of the same year in the Comptes Rendus de la Societé de Biologie. Here is an exerpt of part of his experimental work: "After the section of the cephalic branch of the great sympathetic, it is possible to observe a contraction of the pupil of the corresponding eye, accompanied by a narrowing of the palpebral opening, a retraction of the ocular globe, and an increase of the circulation, as well as of the temperature, in all parts of the corresponding face. If the upper extremitiy of the sectioned sympathetic is galvanized, all the phenomena observed after the removal of the influence of the great sympathetic changes at once, appearing an opposite presentation. The pupil enlarges, the palpebral opening augments, the eye protrudes out the orbit. The former active circulation becomes weak, the conjunctiva, the nose, the ears previously red become pale. If the galvanism is stoped, all phenomena originally produced by the section of the sympathetic gradually reappear, disappearing again after a second galvanic stimulation.”

pioneering comprehension of the nervous system complexity ${ }^{3,9}$. With the publication of his masterwork L'Introduction à l'étude de la médecine expérimentale $(1865)^{10}$ he laid the founding principles of clinical research and of scientific determinism which states that identical experiments should produce identical results ${ }^{2,3}$.

Bernard was a distinguished researcher and experimental medicine philosopher, with several relevant contributions to neurology. 
1. Marduel MA. Claude Bernard un physiologiste natif du Beaujolais, sa famille, sa vie, son oeuvre, 2006. In http://marduel.com/dossiers/ claude-bernard.pdf (May, 24 $4^{\text {th }}, 2013$ ).

2. Foster M. Claude Bernard. London, UK: Fisher Unwin, 1899.

3. Gross CG. Claude Bernard and the constancy of the internal environment. Neuroscientist 1998;4:380-385.

4. Morabia A. Claude Bernard was a 19th century proponent of medicine based on evidence. J Clin Epidemiol 2006;59:1150-1154.

5. Bernard C. L' Oeuvre de Claude Bernard. Introd. par Mathias Duval; notices par E. Renan, Paul Bert et Armand Moreau; table alphabétique et analytique des Oeuvres complètes de Claude Bernard par Roger de La Coudraie; bibliographie des travaux scientifiques par. G. Malloizel. Paris: Baillière in Paris 1881.
Bernard C. Leçons sur la Physiologie et la pathologie du systhème nerveux. Paris: J.-B. Baillière \& Fils., 1858. 2v.

7. Conti F. Claude Bernard's des fonctions du cerveau: an ante litteram manifesto of the neurosciences? Nat Rev Neurosci 2002;3:979-985.

8. Cousin MT. Vulpian and not Claude Bernard first proposed the hypothesis of the motor end-plate as the site of action of curare. Anesthesiology 2002;97:527-528.

9. Bernard C. La science expérimentale. Paris: J.-B. Baillière \& Fils., 1878.

10. Bernard C. Introduction à l'etude de la médecine experiméntale. Baillière. Paris, France, 1865 